\title{
Design a Blended Learning Environment to Teach Arabic Alphabet for Non-Arabic Speaker Children Based on ASSURE Model
}

\author{
Sameer M. AlNajdi
}

\begin{abstract}
Children facing a challenge with learning additional foreign Language, which in terms skills like writing, reading, and pronouncing. This challenge became more difficult when the other language uses different alphabets and writing style. The Arabic language has a different way to write from the English language because it involves writing from right to left and uses different alphabets. Hence, the idea of this work is emerged to find a salutation to train and teach young children the Arabic alphabet using an effective and funny way. A blended lesson was created based on ASSURE model, by using Google Applications, and an Application (Nan and Lyly) on smartphones and tablets to develop the lesson easily to young children and provide practices inside the application and by handwriting in the Face-to-Face class meeting, this blended course will help learners to learn anywhere and anytime, and use the application in their free time. The participant learners in this lesson were students in a USA Elementary school, and after participated in the lesson and its website by watched two deferent videos about how to write and pronounce the alphabet and practiced the in-class activities their writing, pronouncing, and reading improved, but writing skills take more time than pronunciation and reading.
\end{abstract}

Index Terms-Instruction design, ASSURE model, Arabic alphabet, blended learning.

\section{INTRODUCTION}

This lesson created for young children who want to learn Arabic Alphabets. In this lesson, learners had blended methods to learn how to write and pronounce the Arabic Alphabet, blended learning environment gives students the privilege to understand and to explore the real-world issues through authentic learning experiences, facilitated in an online learning environment [1], because learners have the opportunity to review, practice, and re-do the activities and the instruction any time many times learners want in class and online by using technology and media by themselves, and their parents have the authorities to review and use the website to give their children more practice and review the philosophy and instructions of the work in the lesson. Learners participated in all the lesson activities in class and learners had a chance to practice the activates through the website.

The lesson created for young children based on ASSURE model Using some application, such as Google site, Google

Manuscript received February 14, 2017; revised May 21, 2017. This work was supported in part by the Scientific Research Deanship in University of Tabuk under Grant S-0290-1437.

Sameer M. AlNajdi is with the Education Technology Department, University of Tabuk, Saudi Arabia (e-mail: salnajdi@ut.edu.sa).
Document, and Nan and Lyly application designed by Baraem Television [2]. Using technologies in education has more effective ways with young children because learners have been born with these technologies.

According to Smaldino, Lowther, and Russell (2012), "[learners'] control how and when computer provides them with the information they need.... [Also,] computer applications can help with a variety of learning needs" (p. 101) [3]. Blended learning is offering the way to learn traditional and online ways, which help learners to learn and review the course's materials and practice the activities before and after the class meeting.

Learners in this lesson are students in the USA Elementary schools. The researcher narrowed the target learners in this project, but it will work for all who wants to learn Arabic. Target learners in this lesson were second, third, and fifth-grade students, which their ages are from seven years old until 10 years old. This paper was written based on ASSURE Model:
A: Analyze Learners
S: State Objectives
S: Select Methods, Media, and Materials
U: Utilize Media, Materials, and Methods
R: Require Learner Participation
E: Evaluate and Revise.

\section{BLENDED LEARNING CONCEPT}

The concept of Blended Learning refers to the combination of an online learning environment by gaining the flexibility of distance or outside of classroom learning, and a Face-to-Face classroom instruction [4]. Blended learning also affords learners the opportunity to meet with course instructors and their peers face-to-face to discuss, debate, question, and acquire instruction. Courses that are taught completely online obviously do not provide for these physical experiences.

Blended learning combines the benefits of both distance and face-to-face learning. Teachers play the role of facilitators by assisting the students whenever necessary, and the role of instructors by providing complementary lessons in line with the online courses of the students. Halverson, Graham, Spring, and Drysdale (2012), defined blended learning as "a diverse and expanding area of design and inquiry that combines face-to-face and online modalities" ( $p$. 381) [5].

Blended education is comprised of a set of constructs derived from the conventional approaches of learning 
following the properties of pace, delivery mode, number of learners involved, and setting. Blended learning model combines the social components of the traditional didactical methodologies, particularly Face-to-Face communication, with the flexibility and efficiently media technology to facilitate higher education. While these combinations provide significant advantages in providing blended learning, there are also significant drawbacks and challenges created in the process of combining these components. The theory of A. Maslow's Hierarchy of Needs explains the various behaviors exhibited by individuals engaged in blended learning in education, mostly among individuals engaged in distance learning. In applying the Needs Theory of Maslow, the theory suggests the following pedagogical implication for what? According to the proposed needs level: 1) in terms of physiological well-being, no physiological obstacles (e.g. hunger, accessibility, indistinct noises, etc.) must be present to prevent access to learning materials; 2) in terms of safety needs, the learning environment must be able to address the varying needs of students, and at the same time, peers and instructors must be able to provide a psychological feelings of safety to encourage participation; 3) in terms of belongingness needs, the instructor must be able to facilitate a sense of belongingness among learners especially in a group-paced synchronized setting; 4) in terms of esteem needs, individual learning must be fostered to promote active and independent learning; and 5) lastly in terms of self-actualization, the learner must be able to attain a purpose-driven learning process [6].

Blended Learning allows a flexible approach to learning process performed collaboratively by the student, the teacher, and the participating experts or institution. Based on the four constructs identified, the key feature of blended learning is that it can be adjusted, according to the needs of the learner, the course, and the other significant indicators, such as pace, time, and space. Unlike the traditional learning approach, blended learning could offer an array of opportunities for time and space constrained individuals. Blended learning has also been found conceptually effective and applicable in different forms of collaborative learning approaches in cross-disciplines, institutional bridging, and in non-formal settings. Unfortunately, despite the benefits offered by blended learning, the approach has been found to be less adopted by providers due to drawbacks in terms of applicability, integration, and social effects to learners, and cost restriction.

\section{ASSURE MODEL}

ASSURE model is an instructional design model that use to build instruction for learners and to make the instruction more effective and useful for teaching and learning. "ASSURE" is a shortening that stands for the different stages in the model, in each stage of the model there are many actions and steps, these stages are: Analyze Learners, State Objectives, Select Methods, Media, and Materials, Utilize Media, Materials, and Methods, Require Learner Participation, and Evaluate and Revise the instruction before it will be ready to use.

\section{A. Analyze Learners}

This lesson is for learners who are in elementary schools in countries that speak English, and the learners' ages in this lesson will be between seven and 10 years old. The first step of designing a good and effective lesson is to analyze learners to know their characteristics; designers need to know everything about learners; their Cognitive Characteristics, Physiological Characteristics, Affective Characteristics, Social Characteristics, and prior knowledge.

\section{1) Cognitive characteristic}

Learners in this stage are in the concrete operational stage as Piaget placed them in his cognitive development theory. In Piaget's theory, there are four stages of cognitive development experienced by the children during their growth. Each stage represents a period of growth's stages.

1) Sensorimotor stage - up to two years old.

2) Preoperative stage - two to seven years old.

3) Concrete operational stage - seven to eleven years old.

4) Formal operation stage - eleven to fifteen years old.

Participated learners in this stage are starting to think logical, which learners could refer their thinking to activities, and their sensitive [7].

\section{2) Physiological characteristic}

Learners in this stage are active because learners are still in the growing process and some of them could have some disabilities (e.g., hearing trouble or vision trouble). Designers need to ensure to make their lesson fit all their learners, but in general, in this age learners are in good health. Gender in this stage is not an issue to design a deferent instruction based on gender, because finding boys and girls have the same physiological characteristics [8].

\section{3) Social characteristics}

Learners in this stage start growing their social network beyond their family's network, and learners build their independence world. Also, learners start to be competitive by participation in teams' games and emulating their sports, movies, or singer stars.

\section{4) Affective characteristic}

In this characteristic, designers need to check learners' emotional interests, create motivations, review learners' attitudes, check learners' willingness to learn, and evaluate their self-concept and beliefs. Designers need to review all these characteristics to ensure the lessons learners are designing will be effective in achieving its goal.

\section{B. State Objectives}

At the end of this lesson learners achieved the following three goals, each goal of these goals has seven sub-goals based on the seven letters in this lesson:

1) Learners will be able to write the Arabic letter from Alif to Kha by the second try ninety percent correctly.

2) Learners will be able to pronounce the Arabic letter from Alif to Kha by the second try ninety percent correctly.

3) Learners will be able to read the Arabic letter from Alif to Kha by the second try ninety percent correctly.

\section{Select Methods, Media, and Materials}

In this lesson: computer, overhead projector, large screen, 
Whiteboard, papers and pencils, iPads or iPhone to develop the lesson, and PowerPoint slides. In this lesson, the researcher used several methods to achieve the lesson's objectives. The first method to teach learners how to write letters, so learners used the first video on the website to know how the letters. Then learners listened to an Arabic alphabet song provided in the video [9]. Then provided the learners with a chart of Arabic letters designed by Saudi Arabian Culture Mission, 2007; this chart has the letters wrote in Arabic and English, so learners can read the letters name and practice how to pronounce these letters. (See fig. 1). Then learners enrolled in handwriting practices to develop writing skills by using writing chats, which this chart had instruction and help participators to write correctly [10].

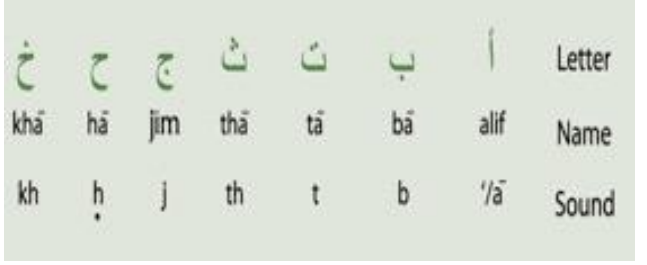

Fig. 1. Arabic letters from Alif to Kha' [11].

After that, learners viewed the second video in the website to find out how the application work and review how to write and pronounce the Arabic alphabet. self-learning method by trying to use an application on the Apple store and the Android market and this application is called Nan and Lyly, (see Fig. 2).

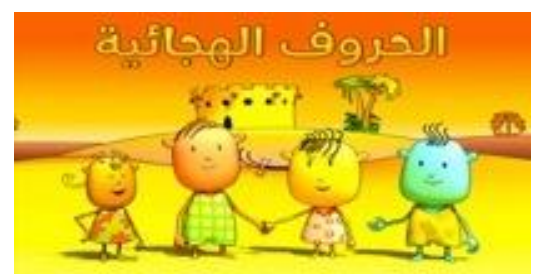

Fig. 2. Homepage of Nan and Lyly application [1].

This application helped learners to write Arabic letters step-by-step (see Fig. 3). Also, listen to the pronunciation of Arabic letters after writing each letter. This application gave immediately sound motivation to learners when learners make mistakes or write the letter right. There are many applications that do the same thing, but after review these applications the designer found this application is the best according to the age stage selected in this study, and it is free to download.

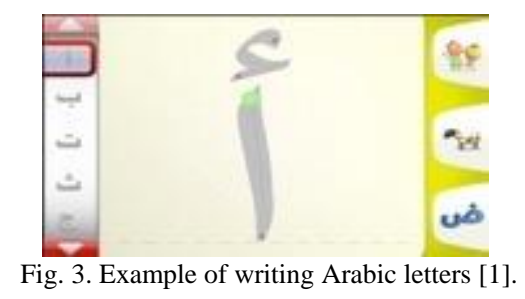

Then cyber-Learning used to develop learners' skills to know the letters shape during their interaction with these the shapes. After that, learners saw the video to refresh their knowledge, the researcher asked the learners to create these letters shapes as a class activity (see Fig. 4). In addition, another class activity will use to help learners to practice handwriting.

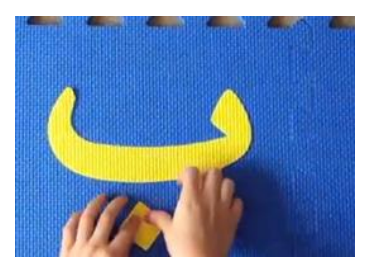

Fig. 4. Cyber-learning of Arabic alphabet.

\section{Utilize Media, Materials, and Methods}

This section is to explain how the researcher used media, materials, and methods. The researcher explained in the previous section how to use these media, materials, and methods. However, most media in this lesson are available from open recourses such as YouTube, Google applications, and Nan and Lyly applications. The researcher created some of these media such as PowerPoint slides, and videos. This lesson used to teach children enrolled in the Sunday school at the Islamic Center in Terre Haute, Indiana, United States of America. The researcher used the environment already created by the school, which has a whiteboard, a data-show projector, a computer and a screen.

In the beginning of the lesson, learners have been asked to sing English alphabet song, and then asked them who know or had memorized the Arabic alphabet. After that, learners listened to Arabic alphabet song and have been asked to listen to the song again. Followed by a pretest to check the learners' knowledge and to check the improvement happened after the lesson by re-using the same test as the posttest.

In addition, and before the lesson started, learners' parents have been asked to provide smart devices to their children during this lesson. Also, additional devices provided in case some of the learners forgot of bringing their devices, so learners did not feel behind.

\section{E. Require Learner Participation}

This lesson has been in three sections, the first section was to involve and motivate learners to explain to them the difference between the Arabic alphabets and English alphabet, the writing of the Arabic alphabets is different from the English alphabets because it involves writing from right to left. The writing process will take more time than pronunciation. The second section has been to introduce and learn the first four letters of the Arabic Alphabets Alif, Ba', Ta', and Tha'. The third section has been for letters Jim, Ha' and Kha. In the last two sections, learners involved in class practice and discussion, group practice, and role-play because this lesson is multimodalities of learning. Learners need to be involved in literacies to get and achieve the goals, these literacies are Text Literacy, Computer Literacy, Distance Literacy, Cyber-Learning Literacy Visual Literacy, Audio Literacy, and Videos Literacy [8].

In this lesson, learners have been involved in the eight literacies; in the Text Literacy learners had to read and write in this lesson, Computer Literacy by used computer and smart devices to train on writing letters, as an environment to the learning when used the Distance Literacy and when learners started to do the class activity, then learners used the internet to listen to the Arabic song and to participated in the 
quiz and went through the website, that is the Cyber-Learning Literacy. Finally, Visual Literacy, Audio Literacy, and Videos Literacy have been on the website by listen to Arabic alphabet song and see videos of how to write letters. Also, learners in this lesson been central of the lesson, and the instructor had been a facilitator.

\section{F. Evaluate and Revise}

In this lesson, learners took two quizzes tests, these quizzes took a place of pretest and posttest to manage the level of achievement, and the effeteness of using this lesson. Both quizzes attached, look at Appendices one and two. In addition, and in the high-level stage parents and instructors could use this with their learners.

\section{1) Rubric}

Using rubric is the way to provide the way to learners and their parents to know how the tests will be grading, and how to get a satisfying grade. The full mark of the test is 50 points, these points have been divided into Six points for the paper organization and professionalism, 42 points for writing and pronounce the Arabic letters as explained in this below rubric table (see Table I).

\begin{tabular}{|c|c|c|c|c|}
\hline & $\begin{array}{l}\text { Not Met } \\
\text { Expectati } \\
\text { ons }\end{array}$ & $\begin{array}{c}\text { Met } \\
\text { Expectatio } \\
\text { ns partly }\end{array}$ & Competent & Proficient \\
\hline Tasks & 0 & 1 & 2 & 3 \\
\hline $\begin{array}{c}\text { Writing the } \\
\text { Arabic } \\
\text { letters }\end{array}$ & $\begin{array}{l}\text { Could net } \\
\text { write the } \\
\text { letter }\end{array}$ & $\begin{array}{l}\text { Wrote the } \\
\text { letter from } \\
\text { third time } \\
\text { or more }\end{array}$ & $\begin{array}{l}\text { Wrote the } \\
\text { Arabic } \\
\text { letter } \\
\text { correctly } \\
\text { from the } \\
\text { first time }\end{array}$ & $\begin{array}{l}\text { Wrote the } \\
\text { Arabic } \\
\text { letter } \\
\text { correctly } \\
\text { from the } \\
\text { first time }\end{array}$ \\
\hline $\begin{array}{l}\text { Pronounce } \\
\text { the Arabic } \\
\text { letters }\end{array}$ & $\begin{array}{l}\text { Could not } \\
\text { pronounce } \\
\text { the letter }\end{array}$ & $\begin{array}{l}\text { Pronounce } \\
\text { the letter } \\
\text { after repeat } \\
\text { it two times } \\
\text { or more }\end{array}$ & $\begin{array}{l}\text { Pronounce } \\
\text { the letter } \\
\text { after repeat } \\
\text { it once }\end{array}$ & $\begin{array}{c}\text { Pronounce } \\
\text { the letter } \\
\text { perfectly }\end{array}$ \\
\hline
\end{tabular}

\section{2) Test}

1) Try to use some of these letters to write three words. The researcher gave hints to figure out how to write these words in Arabic; Dad, Brother, and Door.

2) Record your voice while you are pronouncing the words you wrote.

3) This question is a challenging question; if you answer it you will have extra points.

4) Try to use some of these letters to write three words. The researcher gave hints to figure out how to write these words in Arabic; Dad, Brother, and Door.

5) Record your voice while you are pronouncing the words you wrote.

\section{PhOTO STORY}

The below link is a photo-story about Arabic Alphabet to get a clear view about the letters learners will learn in this lesson. It is will help learners to recognize the Arabic alphabet shape from Alif to Kha, and to know the difference between letters' shapes. http://youtu.be/aZb_oMf_v6M

\section{Multimedia KIT}

In this lesson, the researcher used multimedia kits some of them to the video tutorial (e.g., white screen, Data Show, Laptop, and paper and panicle), and learners will have papers and panicles to write letters. In addition, other stuff will use to present the video tutorial.

After the tutorial finish, learners need to have a tablet to download the application Nan and Lyly. It is available on Apple store in this link, https://appsto.re/us/AXTuz.i, which designed by Baraem TV Channel. Additional iPads have been provided to learners who did not have devices.

\section{Methodology}

The purpose of this lesson is to help kids to write and pronounce the Arabic alphabet from Alif to Kha by using technology; in this lesson, an application is used to help learners to improve their skills in writing and pronouncing, this application is to teach how to write and pronounce the Arabic alphabets, it called Nan and Lyly. The Website is available on this link: https://sites.google.com/site/samlesson13

In this lesson, learners were watching both video clips, which is available on the website, then used the application to train themselves to apply and practice what in the clip contents; by writing the Arabic letters and listen to the letters' pronunciations. After that, learners practiced the handwriting by made several activates are listed on the website. Finally, learners took the quizzes on the website.

The population for this research is all who wants to learn Arabic alphabet, but in this lesson children at Saturdays School in the Islamic Center of Terre Haute in fall 2013 were the lesson's population. A pilot sample from Saturdays School at ICTH chose to participate the formative evaluation; this sample included 40 students; 24 boys and 16 girls, the group's age was from seven to 10 years old.

This report is to summarize the result of the formative evaluation and how this lesson works. This result helped me to revise and develop the website, and to make this website more helpful for students. After that, 40 learners in the Sunday school at ICTH participated in the lesson, the whole lesson took eight individual class, the first meeting was the introduction meeting with the pretest, then each letter had an individual meeting, and between the class meeting online activities was asked to review and the instruction and re-do the handwriting work. At the end, learners take the online test together in the class.

\section{DATA ANALYSIS}

Descriptive statistics (e.g., median, and percentages) used to analyses the data gathered from the students' result. In this lesson, gender is not a factor in this study because learners in this age have the same characteristic. Since the sample was small the researcher used percentages to record the repetitions and analyzed the responses. Percentages show the 
level of students' achievements. In this lesson, write letters by using the application, pronounce the letters correctly, write letters by using paper and panicle, and linked the letter sound with its shape are dependent variables.

\section{RESULTS}

Fourty learners were selected randomly from the first level of Saturday school in the ICTH to participate in the formative evaluation for instruction's video. First of all, learners watched the video, and then got some iPads to use the application by writing the letters from Alif to Kha, and to listen to the pronouncing of these letters. The results show good achievement with writing via the application from the first time, which has been $80 \%$ with no failed, two participators had two chances or more to write the whole letters. In addition, $60 \%$ of them pronounced the whole letters correctly $90 \%$ from the first time, and the $40 \%$ of the participators pronounced the letter correctly after learners reviewed the video twice. When the participators started to use paper and panicle to write the letters; $70 \%$ of them wrote these letters $80 \%$ correctly from the first time. Finally, All the learners linked $100 \%$ correctly the letter sound with its shape from the first time, (see Table II).

The data were collected from the Lesson assessment show great achievement from the learners with using the application, and the handwriting activates, but the percentage of writing the Arabic alphabets dropped down when learners started using paper and panicle to write the Arabic Alphabet, because the application doesn't allow learners to make writing mistakes, which not appear in the handwriting. Also, letter pronunciation has a lower percentage, but in the second try, the percentage raised. On the other hand, learners linked the latter sound with its shape perfectly from the first time, which means learners known the letter sound, but had some trouble with pronunciation.

TABLE II: EVALUATION RESULT

\begin{tabular}{|c|c|c|c|c|}
\hline Tasks & $\begin{array}{l}\text { Number of } \\
\text { participators }\end{array}$ & $\begin{array}{c}\text { Percentage } \\
\text { of achieved } \\
\text { in the } \\
\text { pretest }\end{array}$ & $\begin{array}{l}\text { Percentage } \\
\text { of } \\
\text { achieved } \\
\text { the goal in } \\
\text { post-test } \\
\text { from first } \\
\text { time }\end{array}$ & $\begin{array}{l}\text { Percentage } \\
\text { of } \\
\text { achievement } \\
\text { the goal in } \\
\text { post-test } \\
\text { from the } \\
\text { second time }\end{array}$ \\
\hline $\begin{array}{l}\text { Write letters in } \\
\text { the application }\end{array}$ & 40 & $30 \%$ & $80 \%$ & $100 \%$ \\
\hline $\begin{array}{l}\text { Pronounce the } \\
\text { letters correctly }\end{array}$ & 40 & $20 \%$ & $60 \%$ & $90 \%$ \\
\hline $\begin{array}{c}\text { Write letters by } \\
\text { handwriting }\end{array}$ & 40 & $30 \%$ & $70 \%$ & $80 \%$ \\
\hline $\begin{array}{c}\text { Linked the letter } \\
\text { sound with its } \\
\text { shape }\end{array}$ & 40 & $30 \%$ & $100 \%$ & $100 \%$ \\
\hline
\end{tabular}

\section{CONCLUSION}

After reviewed the results from the data, the researcher found the website helped the learners to achieve new level with writing in the application by raised the percentage of achievement from $30 \%$ to $100 \%$ after took the lesson twice, and all learners passed to link the letters' sound with its shape after the first time of taking the lesson. In addition, when learners started the handwriting the percentage of achievement raised from $30 \%$ to $80 \%$, which shows great progress in their skills, and the percentage of achievement of pronouncing the Arabic alphabets raised from 20\% to $90 \%$ after took the lesson twice.

In conclusion, the application helped the learners to recognize the letter's shape, and its sound, pronounce and write the Arabic alphabets, but learners need to practice writing and listen to the letters' sounds that help them with the handwriting and pronunciation, by focusing more on handwriting activities, with training on the letter sound by giving examples of words started with the letters, so learners will remember the sound of the letter and have advance practices of the letter sounds in the beginning of some words, in middle of words, and at the end of words. The whole lesson needs to have more classes activities to practice the handwriting and the pronunciation of the Arabic alphabet. In addition, the website will help parents to follow up with their children to practice more and use the related links to educate their children in the whole Arabic alphabets by following the same steps in this lesson.

\section{REFERENCES}

[1] A. K. Ellis, "Teaching, learning, and assessment together: The reflective classroom," London: Eye on Education, 2001.

[2] T. V. Baraem. (2011). Nan and Lyly. [Mobile application software]. [Online]. Available: https://itunes.apple.com/us/app/alhrwf-alhjayyt-m-nan-w-lyly/id4248 $60762 ? \mathrm{mt}=8$

[3] S. E. Smaldino et al., Instructional Technology and Media for Learning, Upper Saddle River, N.J: Pearson Merrill Prentice Hall, 2012.

[4] M. Hentea et al., "A perspective on fulfilling the expectations of distance education," in Proc. CITC4 '03 the 4th Conference on Information Technology Curriculum, New York: ACM, 2003.

[5] L. R. Halverson et al., "An analysis of high impact scholarship and publication trends in blended learning," Distance Education, vol. 33 , no. 3, pp. 381-413, 2012

[6] E. Chew et al., "Critical review of the blended learning models based on Maslow's and Vygotsky's educational theory," in Proc. First International Conference on Hybrid Learning and Education, pp. 40-53, 2008.

[7] M. D. Smith, Educational Psychology and Its Classroom Applications, Boston: Allyn and Bacon, 1975.

[8] S. N. Elliott, Educational Psychology: Effective Teaching, Effective Learning, Boston: McGraw-Hill, 2000.

[9] Syraj Teach Children Arabic. (2011). Learn the Arabic Alphabet Song! Teach Kids Arabic Free! [Online]. Available: https://www.youtube.com/watch? v=0xYy3D6zYgY

[10] Z. Qureshi, "Arabic writing for beginners: Part I. Chicago, IL: Kazi publication INC a Saudi Arabian culture mission," 2007.

[11] SACM. (2007) Arabic alphabets cheat. [Online]. Available: http://www.sacm.org/ArabicSACM/default.aspx

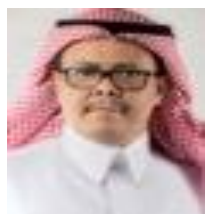

Sameer M. AlNajdi is an assistant professor of education technology at University of Tabuk, Saudi Arabia. He received his $\mathrm{PhD}$ degree in curriculum and instruction with specialization of educational technology and got an instructional design certificate from Indiana State university, Terre Haute, IN, USA. Dr. AlNajdi is currently the dean of development and quality assurance deanship at University of Tabuk. His research interests include instructional design, flipped education, e-learning, Mobile learning, MOOC, and using technology to develop learning environments. 